\title{
GAMBARAN PROFIL LIPID PADA PENDERITA SINDROM KORONER AKUT DI RSUP. PROF. DR. R. D. KANDOU PERIODE JANUARI - SEPTEMBER 2015
}

\author{
${ }^{1}$ Eva Nur Faridah \\ ${ }^{2}$ Janry A. Pangemanan \\ ${ }^{2}$ Starry H. Rampengan
}

\begin{abstract}
${ }^{1}$ Kandidat Skripsi Fakultas Kedokteran Universitas Sam Ratulangi Manado
${ }^{2}$ Bagian Kardiologi Fakultas Kedokteran Universitas Sam Ratulangi Manado Email: flaurinevha@rocketmail.com
\end{abstract}

\begin{abstract}
Acute coronary syndrome (ACS) is due to plaque rupture or erosion of atherosklerosis, including unstable angina pectoris, non-ST elevation myocardial infarction, and ST-elevation myocardial infarction. In indonesia, ACS is still regarded as the highest death contributor. One of the risk factors of ACS is dyslipidemia, that is abnormality condition of lipid in blood. Objective: This study aims to determine description of lipid profile in patients with acute coronary syndrome. Methods: This was a descriptive observational method, based on the secondary data from patients in CVBC Prof. Dr. R. D. Kandou Hospital during January to September 2015. Result: The result showed that from 80 patients of ACS were 37 patients (46,25\%) with high total cholsterol levels ( $\geq 200 \mathrm{mg} / \mathrm{dL}), 70$ patients $(87,5 \%)$ with low HDL cholesterol levels $(\leq 40-50 \mathrm{mg} / \mathrm{dL})$, there are 58 patients (72,5\%) with high LDL cholesterol levels (> $100 \mathrm{mg} / \mathrm{dL})$ and 32 patients (40\%) with high triglycerides levels $(\geq 150 \mathrm{mg} / \mathrm{dL}$ ). Conclusion: Most of ACS patients in this research had high LDL cholesterol levels and low HDL cholesterol levels.
\end{abstract}

Keywords: Acute coronary syndrome, dyslipidemia, lipid profile

\begin{abstract}
Abstrak: Sindrom koroner Akut ( SKA ) terjadi karena adanya ruptur atau erosi dari plak aterosklerosis, termasuk angina pektoris tidak stabil, non-ST elevasi miokard infark, dan ST elevasi miokard infark. Di Indonesia, SKA masih di anggap sebagai penyumbang angka kematian tertinggi. Salah satu faktor risiko SKA adalah dislipidemia, yaitu berupa gangguan metabolisme lipid. Tujuan: Penelitian ini bertujuan untuk mengetahui gambaran profil lipid pada penderita sindrom koroner akut. Metode: Penelitian ini bersifat deskriptif observasional dengan menggunakan data sekunder dari penderita SKA di CVBC RSUP. Prof. Dr. R. D. Kandou periode januari - september 2015. Hasil: Hasil penelitian ini menunjukkan dari 80 penderita SKA didapatkan 37 orang (46,25\%) adalah penderita yang memiliki kadar kolesterol total tinggi ( $\geq 200 \mathrm{mg} / \mathrm{dL}$ ), sebanyak 70 orang $(87,5 \%)$ memiliki kadar HDL rendah $(\leq 40-50 \mathrm{mg} / \mathrm{dL})$, adapun yang memiliki kadar LDL tinggi $(>100 \mathrm{mg} / \mathrm{dL}$ ) yaitu 58 orang $(72,5 \%)$ dan 32 orang $(40 \%)$ adalah penderita yang memiliki kadar trigliserida tinggi $(\geq 150$ mg/dL). Kesimpulan: Penderita sindrom koroner akut dalam penelitian ini sebagian besar memiliki kadar kolesterol LDL yang tinggi dan kadar kolesterol HDL yang rendah.
\end{abstract}

Kata kunci: Sindrom koroner akut, dislipidemia, profil lipid 
Sindrom koroner akut (SKA) merupakan kegawatan jantung yang terjadi karena adanya ruptur atau erosi dari plak aterosklerosis yang memiliki gambaran berupa angina pektoris tidak stabil (unstable angina pectoris/UAP), infark miokardium akut (IMA) baik dengan peningkatan segmen ST (ST segmen elevation myocardial infarction/STEMI) maupun tanpa peningkatan segmen ST (non ST segmen elevation myocardial infarction/NSTEMI). ${ }^{1,2}$

Kadar kolesterol darah merupakan faktor risiko utama proses aterosklerosis yang mendasari terjadinya penyakit jantung koroner ( PJK ) termasuk sindrom koroner akut. Aterosklerosis adalah kelainan yang ditandai dengan peradangan pembuluh darah dan peradangan ini merupakan pusat dari semua tahap aterosklerosis. Sindrom koroner akut secara signifikan mempengaruhi konsentrasi, komposisi lipid dan lipoprotein dalam plasma yaitu peningkatan kolesterol total, kolesterol LDL dan trigliserida, sementara kolesterol HDL menurun. ${ }^{3}$

Penyakit kardiovaskular masih merupakan masalah terbesar yang menjadi penyebab kematian di negara indrustri dan berkembang. Menurut WHO, 12,8\% dari 7.254.000 kematian diseluruh dunia disebabkan oleh SKA pada tahun 2008. Di USA setiap tahun 550.000 orang meninggal karena penyakit ini. Di Eropa diperhitungkan 20-40.000 orang dari 1 juta penduduk menderita SKA. ${ }^{4}$ Di Indonesia, SKA juga masih di anggap sebagai penyumbang angka kematian tertinggi, prevalensi nasional penyakit jantung di Indonesia sebesar 7,2\% (berdasarkan diagnosis tenaga kesehatan dan gejala) sedangkan prevalensi di Sulawesi Utara adalah sebesar 8,2\%.

Secara garis besar faktor risiko sindrom koroner akut dapat dibagi dua. Pertama adalah faktor risiko yang dapat diperbaiki (reversible) atau bisa diubah (modifiable), yaitu: Dislipidemia (LDL meningkat, HDL menurun), Merokok,
Hipertensi, Diabetes Melitus, Sindrom Metabolik, Kurang aktivitas fisik. Sedangkan faktor risiko yang tidak dapat diperbaiki diantaranya: Usia lanjut, Jenis kelamin, Herediter. $^{5}$

Sebagian besar SKA adalah manifestasi akut dari plak ateroma pembuluh darah koroner yang koyak atau pecah. Hal ini berkaitan dengan perubahan komposisi plak dan penipisan tudung fibrus yang menutupi plak tersebut. Kejadian ini akan diikuti oleh proses agregasi trombosit dan aktivasi jalur koagulasi. Terbentuklah trombus yang kaya trombosit (white trombus). Trombus ini akan menyumbat liang pembuluh darah koroner, baik secara total maupun parsial. Selain itu, terjadi pelepasan zat vasoaktif yang menyebabkan vasokonstriksi sehingga memperberat gangguan aliran darah koroner. Berkurangnya aliran darah koroner menyebabkan iskemia miokardium. Pasokan oksigen yang berhenti selama kurang-lebih 20 menit menyebabkan miokardium mengalami nekrosis (infark miokard). Disisi lain, sebagian pasien SKA tidak mengalami koyak plak seperti yang diteranngkan di atas. Mereka mengalami SKA karena obstruksi dinamis akibat spasme lokal dari arteri koronaria epikardial (Angina Prinzmetal). Penyempitan arteri koronaria, tanpa spasme maupun trombus, dapat diakibatkan oleh progresi plak atau restenosis setelah Intervensi Koroner Perkutan (IKP). Beberapa faktor ekstrinsik, seperti demam, anemia, tirotoksikosis, hipertensi, takikardia, dapat menjadi pencetus terjadinya SKA pada pasien yang telah mempunyai plak aterosklerosis. ${ }^{6}$

Seperti yang telah dijelaskan sebelumnya bahwa salah satu faktor risiko SKA adalah dislipidemia yaitu gangguan metabolisme lipid berupa peningkatan kadar kolesterol total, trigliserida (TG), low density lipoprotein (LDL), dan penurunan kadar high density lipoprotein (HDL). ${ }^{7}$ Apabila dislipidemia tidak segera diatasi, maka dapat terjadi berbagai macam komplikasi, antara lain atherosklerosis, 
penyakit jantung koroner, penyakit serebrovaskular seperti stroke, kelainan pembuluh darah tubuh lainya, dan pankreatitis akut. Dislipidemia disebabkan oleh terganggunya metabolisme lipid akibat interaksi faktor genetik dan faktor lingkungan. Walau terdapat bukti hubungan antara kadar kolesterol total dengan kejadian kardiovaskular, hubungan ini dapat menyebabkan kesalahan interpretasi ditingkat individu seperti pada wanita yang sering mempunyai konsentrasi kolesterol HDL yang tinggi. Kejadian serupa juga dapat ditemukan pada subjek dengan DM atau sindrom metabolik dimana konsentrasi kolesterol HDL sering ditemukan rendah. Pada keadaan ini, penilaian resiko hendaknya mengikutsertakan analisis berdasarkan konsentrasi kolesterol HDL dan LDL., ${ }^{8,9}$

Terdapat bukti kuat adanya hubungan antara kolesterol LDL dengan kejadian kardiovaskular berdasarkan studi luaran klinis. Sehingga kolesterol LDL merupakan target utama dalam tatalaksana dislipidemia. Besarnya reduksi risiko kardiovaskular sesuai dengan besarnya penurunan kolesterol LDL. Setiap penurunan $1 \mathrm{mmo} / \mathrm{L}$ (40mg/dL) kolesterol LDL berhubungan dengan reduksi 22\% mortalitas dan morbiditas kardiovaskular. Kolesterol HDL dapat memprediksi kejadian kardiovaskular bahkan pada pasien yang telah diterapi dengan statin namun hubungan peningkatan konsentrasi kolesterol HDL dengan proteksi kardiovaskular tidak meyakinkan karena, bila target kolesterol LDL sudah tercapai, peningkatan kolesterol HDL tidak menurunkan resiko kardiovaskular. ${ }^{9}$

Peran peningkatan konsentrasi Trigliserida sebagai prediktor terhadap penyakit kardiovaskular masih menjadi perdebatan. Hubungan antara Trigliserida puasa dengan risiko kardiovaskular yang didapat berdasarkan analisis univariat melemah setelah dilakukan penyesuaian terhadap faktor lain terutama kolesterol HDL. Konsentrasi Trigliserida yang tinggi sering disertai dengan konsentrasi kolesterol HDL rendah dan konsentrasi small, dense LDL yang tinggi sehingga diperkirakan pengaruh hipertrigliseridemia terhadap risiko kardiovaskular secara tidak langsung disebabkan oleh konsentrasi kolesterol HDL rendah dan konsentrasi small, dense LDL tinggi. ${ }^{9}$

Ada 2 pedoman tatalaksana dislipidemia yang besar yaitu European Society of Cardiology (ESC) dan European Atherosklerosis Society (EAS) tahun 2011 dimana karya tulis ilmiah ini sebagian besar menggunakan referensi dan mengacu pada ke 2 pedoman tersebut. $^{9}$ Rekomendasi profil lipid yang diperiksa secara rutin adalah kolesterol total, kolesterol LDL, kolesterol HDL dan Trigliserida. Dimana yang telah dijelaskan sebelumnya bahwa LDL adalah sebagai target terapi primer dislipidemia dimana penurunan kolesterol LDL dalam hal ini disesuaikan dengan faktor risiko masingmasing penderita. Target terapi LDL bagi pasien dengan risiko kardiovaskular sangat tinggi adalah $<70 \mathrm{mg} / \mathrm{dL}$ atau penurunan $\geq 50 \%$ dari konsentrasi awal. Bagi pasien dengan risiko tinggi, target terapinya adalah $<100 \mathrm{mg} / \mathrm{dL}$ atau penurunan $\geq 30 \%$ dari konsentrasi awal. Target terapi kolesterol LDL bagi pasien berisiko menengah adalah $<115 \mathrm{mg} / \mathrm{dL}$. Sedangkan bagi yang berisiko rendah, target terapi harus mempertimbangkan keuntungan dan kerugian terapi obat penurun lipid. ${ }^{9}$

\section{METODE PENELITIAN}

\section{Jenis Penelitian}

Penelitian ini bersifat deskriptif observasional dengan cara mengumpulkan data rekam medik pasien SKA selama periode Januari - September 2015.

\section{Tempat dan Waktu Penelitian}

Penelitian ini dilakukan di Bagian Rekam Medik CVBC RSUP Prof. Dr. R. D. Kandou Manado pada bulan Oktober Desember 2015. 


\section{Populasi dan Sampel Penelitian}

Populasi dari penelitian ini adalah semua data rekam medik penderita yang didiagnosis SKA dan dirawat inap di CVBC RSUP Prof. Dr. R. D. Kandou periode Januari-September 2015. Sampel penelitian ini mencakup seluruh populasi dengan kriteria yaitu semua pasien yang didiagnosis SKA dengan kelengkapan data mencakup nama, umur, jenis kelamin dan pemeriksaan lab (Profil Lipid) di CVBC
RSUP Prof. Dr. R. D. Kandou selama periode Januari - September 2015.

\section{Analisis Data}

Analisis data dilakukan secara manual dengan mencatat data dari rekam medik kemudian data ditabulasikan dan ditampilkan dengan bentuk tabel dan tulisan serta menggunakan Statistical Program for Social Science (SPSS) versi 20 untuk mencari nilai rerata dan standard deviasi.

\section{HASIL PENELITIAN}

Tabel 1. Baseline Karakteristik Penderita Sindrom Koroner Akut

\begin{tabular}{|c|c|c|c|c|}
\hline \multirow[t]{2}{*}{ Karakteristik } & \multicolumn{3}{|c|}{ Sindrom Koroner Akut } & \multirow[b]{2}{*}{$\begin{array}{c}\text { Total } \\
(\mathrm{n}=80)\end{array}$} \\
\hline & $\begin{array}{c}\text { UAP } \\
(\mathrm{n}=37)\end{array}$ & $\begin{array}{c}\text { NSTEMI } \\
(\mathrm{n}=33)\end{array}$ & $\begin{array}{l}\text { STEMI } \\
(\mathrm{n}=10)\end{array}$ & \\
\hline \multicolumn{5}{|l|}{ Jenis } \\
\hline \multicolumn{5}{|l|}{ Kelamin } \\
\hline Laki-laki & $23(28,75 \%)$ & $22(27,5 \%)$ & $8(10 \%)$ & $53(66,25 \%)$ \\
\hline Perempuan & $14(17,5 \%)$ & $11(13,75 \%)$ & $2(2,5 \%)$ & $27(33,75 \%)$ \\
\hline \multicolumn{5}{|l|}{ Umur (th) } \\
\hline $36-45$ & $2(2,5 \%)$ & $1(1,25 \%)$ & - & $3(3,75 \%)$ \\
\hline $46-55$ & $8(10 \%)$ & $8(10 \%)$ & $4(5 \%)$ & $20(25 \%)$ \\
\hline $56-65$ & $17(21,25 \%)$ & $14(17,5 \%)$ & $3(3,75 \%)$ & $34(42,5 \%)$ \\
\hline$>65$ & $10(12,5 \%)$ & $11(13,75 \%)$ & $2(2,5 \%)$ & $23(28,75 \%)$ \\
\hline \multicolumn{5}{|l|}{ Faktor } \\
\hline Hipertensi & $7(8,75 \%)$ & $6(7,5 \%)$ & $3(3,75 \%)$ & $16(20 \%)$ \\
\hline DM II & $5(6,25 \%)$ & $9(11,25 \%)$ & - & $14(17,5 \%)$ \\
\hline Dislipidemia & $4(5 \%)$ & $3(3,75 \%)$ & $1(1,25 \%)$ & $8(10 \%)$ \\
\hline Kombinasi & $9(11,25 \%)$ & $2(2,5 \%)$ & $4(5 \%)$ & $15(18,75 \%)$ \\
\hline Tidak ada & $12(15 \%)$ & $13(16,25 \%)$ & $2(2,5 \%)$ & $27(33,75 \%)$ \\
\hline
\end{tabular}


Tabel 2. Distribusi Penderita Sindrom Koroner Akut Berdasarkan Profil Lipid

\begin{tabular}{cccc}
\hline & \multicolumn{3}{c}{ Sindrom Koroner Akut } \\
\cline { 2 - 4 } $\begin{array}{c}\text { Profil Lipid } \\
(\mathrm{mg} / \mathrm{dL})\end{array}$ & $\begin{array}{c}\text { UAP } \\
(\mathrm{n}=37)\end{array}$ & $\begin{array}{c}\text { NSTEMI } \\
(\mathrm{n}=33)\end{array}$ & $\begin{array}{c}\text { STEMI } \\
(\mathrm{n}=10)\end{array}$ \\
\cline { 2 - 4 } & Rerata \pm SB & Rerata \pm SB & Rerata \pm SB \\
\hline & & & \\
Kolesterol & & & \\
Total & $196,7 \pm 47,764$ & $184,06 \pm 44,292$ & $217,9 \pm 32,882$ \\
HDL & $41,03 \pm 20,682$ & $40,45 \pm 894$ & $36,8 \pm 4,78$ \\
LDL & $130,19 \pm 437$ & $117,73 \pm 631$ & $146,5 \pm 22,402$ \\
Trigliserida & $152,27 \pm 176$ & $132,58 \pm 866$ & $135,3 \pm 63,174$ \\
\hline
\end{tabular}

Tabel 3. Rerata Profil Lipid Penderita Sindrom Koroner Akut

\begin{tabular}{|c|c|c|c|c|}
\hline \multirow{2}{*}{$\begin{array}{c}\text { Profil } \\
\text { Lipid } \\
(\mathrm{mg} / \mathrm{dL})\end{array}$} & \multicolumn{4}{|c|}{ Sindrom Koroner Akut } \\
\hline & $\begin{array}{l}\text { UAP } \\
(\mathrm{n}=37)\end{array}$ & $\begin{array}{c}\text { NSTEMI } \\
(\mathrm{n}=33)\end{array}$ & $\begin{array}{l}\text { STEMI } \\
(\mathrm{n}=10)\end{array}$ & $\begin{array}{c}\text { Total } \\
(\mathrm{n}=80)\end{array}$ \\
\hline \multicolumn{5}{|c|}{ Kolesterol Total } \\
\hline$<200$ & $20(25 \%)$ & $20(25 \%)$ & $3(3,75 \%)$ & $43(53,75 \%)$ \\
\hline$\geq 200$ & $17(21,25 \%)$ & $13(16,25 \%)$ & $7(8,75 \%)$ & $37(46,25 \%)$ \\
\hline \multicolumn{5}{|l|}{ HDL } \\
\hline \multicolumn{5}{|l|}{$\leq 40-$} \\
\hline \multicolumn{4}{|l|}{50 (lk- } & $70(87,5 \%)$ \\
\hline$>50$ & $4(5 \%)$ & $6(7,5 \%)$ & - & $10(12,5 \%)$ \\
\hline \multicolumn{5}{|l|}{ LDL } \\
\hline$<100$ & $10(12,5 \%)$ & $12(15 \%)$ & - & $22(27,5 \%)$ \\
\hline $100-129$ & $11(13,75 \%)$ & $8(10 \%)$ & $2(2,5 \%)$ & $21(26,25 \%)$ \\
\hline 130-159 & $8(10 \%)$ & $8(10 \%)$ & $6(7,5 \%)$ & $22(27,5 \%)$ \\
\hline $160-189$ & $5(6,25 \%)$ & $4(5 \%)$ & $2(2,5 \%)$ & $11(13,75 \%)$ \\
\hline$\geq 190$ & $3(3,7575 \%)$ & $1(1,25 \%)$ & - & $4(5 \%)$ \\
\hline \multicolumn{5}{|c|}{ Trigliserida } \\
\hline$<150$ & $19(23,75 \%)$ & $23(28,75 \%)$ & $6(7,5 \%)$ & $48(60 \%)$ \\
\hline$\geq 150$ & $18(22,5 \%)$ & $10(12,5 \%)$ & $4(5 \%)$ & $32(40 \%)$ \\
\hline
\end{tabular}


Tabel 4. Distribusi Penderita Sindrom Koroner Akut dengan Faktor Risiko Dislipidemia Berdasarkan Profil Lipid

\begin{tabular}{ccccc}
\hline $\begin{array}{c}\text { Profil Lipid } \\
(\mathrm{mg} / \mathrm{dL})\end{array}$ & $\begin{array}{c}\text { UAP } \\
(\mathrm{n}=14)\end{array}$ & $\begin{array}{c}\text { NSTEMI } \\
(\mathrm{n}=4)\end{array}$ & $\begin{array}{c}\text { STEMI } \\
(\mathrm{n}=2)\end{array}$ & $\begin{array}{c}\text { Total } \\
(\mathrm{n}=20)\end{array}$ \\
\cline { 2 - 5 } & & & & \\
\multicolumn{5}{c}{ Kolesterol Total } \\
$<200$ & $5(25 \%)$ & $2(10 \%)$ & - & $7(35 \%)$ \\
$\geq 200$ & $9(45 \%)$ & $2(10 \%)$ & $2(10 \%)$ & $13(65 \%)$ \\
HDL & & & & \\
$\leq 40-50(\mathrm{lk}-$ & & & & \\
pr $)$ & $11(55 \%)$ & $2(10 \%)$ & $2(10 \%)$ & $15(75 \%)$ \\
$>50$ & $3(15 \%)$ & $2(10 \%)$ & - & $5(25 \%)$ \\
LDL & & & & $3(15 \%)$ \\
$<100$ & $2(10 \%)$ & $1(5 \%)$ & - & $6(30 \%)$ \\
$100-129$ & $4(20 \%)$ & $2(10 \%)$ & - & $5(25 \%)$ \\
$130-159$ & $3(15 \%)$ & $1(5 \%)$ & $1(5 \%)$ & $5(15 \%)$ \\
$160-189$ & $2(10 \%)$ & - & $1(5 \%)$ & $3(15 \%)$ \\
$\geq 190$ & $3(15 \%)$ & - & - & $3(35 \%)$ \\
Trigliserida & & & \\
$<150$ & $4(20 \%)$ & $2(10 \%)$ & $1(5 \%)$ & $7(35 \%)$ \\
$\geq 150$ & $10(50 \%)$ & $2(10 \%)$ & $1(5 \%)$ & $13(65 \%)$ \\
\hline \multicolumn{5}{c}{}
\end{tabular}

Tabel 5. Rerata Profil Lipid Penderita Sindrom Koroner Akut dengan Faktor Risiko Dislipidemia

\begin{tabular}{cccc}
\hline & \multicolumn{3}{c}{ Sindrom Koroner Akut } \\
\cline { 2 - 4 } $\begin{array}{c}\text { Profil } \\
\text { Lipid }\end{array}$ & UAP & NSTEMI & STEMI \\
$(\mathrm{mg} / \mathrm{dL})$ & $(\mathrm{n}=14)$ & Rerata \pm SB & Rerata \pm SB \\
\cline { 2 - 4 } & Rerata \pm SB & & \\
\hline & & & \\
Kolesterol & & & \\
Total & $224,57 \pm 53,223$ & $191,25 \pm 31,563$ & $241 \pm 53,74$ \\
HDL & $39,93 \pm 14,793$ & $48,25 \pm 17,633$ & $42,5 \pm 707$ \\
LDL & $151 \pm 52,065$ & $116,75 \pm 38,681$ & $159 \pm 32,527$ \\
Trigliserida & $160,14 \pm 47,822$ & $132 \pm 75,237$ & $196 \pm 101,823$ \\
\hline
\end{tabular}

\section{PEMBAHASAN}

Populasi penderita sindrom koroner akut yang dirawat inap di CVBC RSUP. Prof. Dr. R. D. Kandou selama periode januari september 2015 adalah sebanyak 105 pasien, namun yang memenuhi kriteria inklusi penelitian ini hanya sebanyak 80 pasien. Dari 80 pasien didapatkan jumlah penderita paling banyak menurut diagnosisnya adalah penderita angina tidak stabil yakni 37 orang dan penderita infark miokard tanpa peningkatan elevasi ST yakni sebanyak 33 orang sedangkan yang paling sedikit adalah penderita infark miokard dengan elevasi ST yakni 
berjumlah 10 orang. Hal ini tidak sesuai dengan penelitian yang dilakukan oleh Siniawski $^{10}$ dkk dimana dari total keseluruhan sampel didapatkan 51\% penderita dengan diagnosis STEMI. Hal ini dapat disebabkan oleh perbedaan negara yang dapat mempengaruhi faktor risiko dan gaya hidup penderita.

Berdasarkan jenis kelaminnya didapatkan jumlah terbanyak adalah lakilaki yakni berjumlah 53 orang dan perempuan hanya berjumlah 27 orang. Risiko laki-laki untuk terkena penyakit kardiovaskular adalah 2-3 kali lipat lebih tinggi dibanding perempuan pada rentang usia remaja hingga lima puluh tahun karena selama masa pre menopause estrogren meningkatkan kadar HDL dan menurunkan kadar LDL. ${ }^{11}$ Hasil ini serupa dengan penelitian yang dilakukan oleh Torry $^{12}$ pada tahun 2011-2012 yang menunjukkan dimana penderita laki-laki berjumlah 32 orang dan penderita perempuan hanya berjumlah 12 orang, mekanisme yang bisa mendasari hal ini adalah peran hormon estrogen dan progesteron pada wanita yang mempunyai faktor protektif terhadap kejadian penyakit jantung koroner. ${ }^{11}$

Hasil penelitian ini menunjukkan bahwa penderita terbanyak adalah pada kelompok usia 46 - 65 tahun yakni sebanyak 54 orang. Hal ini serupa dengan penelitan yang dilakukan oleh Ramadhani ${ }^{13}$ pada tahun 2010 dimana penderita terbanyak yaitu sebesar 98\% didapat pada usia 41 sampai dengan usia > 60 tahun. Perubahan usia adalah salah satu faktor risiko kuat untuk penyakit sindrom koroner akut (SKA) tetapi faktor risiko lainnya dan kondisi komorbid juga memiliki pengaruh yang sangat besar ${ }^{13}$ dimana juga perubahan gaya hidup mempengaruhi tingkat kejadian sindrom koroner akut pada usia. Teori menyebutkan bahwa skrining faktor risiko, termasuk profil lipid, dapat dipertimbangkan pada pria dewasa usia $\geq 40$ tahun, dan pada wanita usia $\geq 50$ tahun atau pasca- menopause, terutama pasien yang memiliki faktor risiko lain. ${ }^{14}$

Pada penelitian profil lipid didapatkan 43 orang memiliki kadar kolesterol total < $200 \mathrm{mg} / \mathrm{dL}$. Pada penderita SKA dengan faktor risiko dislipidemia didapatkan lebih banyak penderita yang memiliki kadar kolesterol total $\geq 200 \mathrm{mg} / \mathrm{dL}$ yaitu 13 orang. Nilai tersebut menunjukkan bahwa pasien terbanyak yakni memiliki kadar kolesterol total dalam kelompok optimal. Sedangkan jika dilihat berdasarkan diagnosis penyakit penderita didapatkan rerata kolesterol total paling tinggi pada kelompok STEMI yaitu sebesar 217,9+32,882 mg/dL. Hal tersebut sama seperti nilai rerata yang didapat pada penderita SKA dengan faktor risiko dislipidemia dimana rerata kadar kolesterol total tertinggi juga didapatkan pada

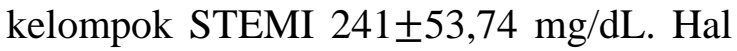
ini sesuai dengan penelitian yang dilakukan oleh Rudyanto ${ }^{15}$ dimana penderita PJK terbanyak yakni berjumlah 61 orang yang memiliki kadar kolesterol total normal. Bila kadar kolesterol total darah mencapai >200 mg/dL maka, kolesterol tersebut akan disimpan dan menempel didalam pembuluh darah sehingga nantinya akan menimbulkan pengendapan kolesterol didalam pembuluh darah, hal tersebut menyebabkan risiko untuk terjadinya PJK semakin meningkat. Secara klinis pemeriksaan kolesterol total digunakan untuk menentukan faktor risiko penyakit jantung, walau secara patofisiologi yang berperan sebagai faktor risiko adalah kolesterol LDL. ${ }^{16}$

Pada kolesterol HDL didapatkan hampir keseluruhan pasien memiliki kolesterol HDL $\leq 40-50 \mathrm{mg} / \mathrm{dL}$ pada lakilaki maupun pada perempuan . Pada penderita SKA dengan faktor risiko dislipidemia didapatkan juga lebih banyak penderita yang memiliki kadar kolesterol HDL $\leq$ 40-50 mg/dL. Nilai tersebut menunjukkan bahwa hampir keseluruhan penderita memiliki kadar kolesterol HDL dalam kelompok yang perlu diwaspadai. Sedangkan pada nilai rerata penurunan 
kadar kolesterol HDL paling rendah didapat pada kelompok STEMI yakni sebesar 36,8 $\pm 4,78 \mathrm{mg} / \mathrm{dL}$. Pada penderita SKA dengan faktor risiko dislipidemia didapatkan rerata penurunan HDL paling rendah adalah pada kelompok UAP yaitu $39,93 \pm 14,793 \mathrm{mg} / \mathrm{dL}$. Hal ini sesuai dengan penelitian yang dilakukan oleh Manurung $^{17}$ di RS Cipto Mangunkusumo Jakarta dimana pasien dengan kadar kolesterol HDL dibawah optimal yakni dalam kadar rendah lebih banyak yaitu berjumlah 152 orang. Kadar kolesterol HDL yang tinggi memberi pengaruh yang baik bagi tubuh. HDL merupakan jenis kolesterol yang bersifat baik atau menguntungkan; berfungsi mengangkut kolesterol yang berlebih yang terdeposit didalam pembuluh darah maupun jaringan tubuh lainnya menuju ke hati untuk di eliminasi melalui traktus gastrointestinal. Semakin tinggi kadar HDL, maka akan semakin besar pula kapasitas untuk memindahkan kolesterol dan mencegah terjadinya aterosklerosis. ${ }^{18,19}$ Beberapa faktor seperti faktor genetik, diabetes melitus tipe 2, dan obat-obat tertentu dapat menurunkan kadar kolesterol HDL. Merokok, obesitas, dan pola hidup yang buruk juga bisa mengakibatkan penurunan kadar kolesterol HDL. ${ }^{11}$

Pada penelitian kolesterol LDL didapatkan penderita terbanyak adalah yang memiliki kadar kolesterol LDL $\geq 100$ mg/dL berjumlah 58 orang. Pada penderita SKA dengan faktor risiko dislipidemia didapatkan juga lebih banyak penderita yang memiliki kadar kolesterol LDL $\geq 100$ $\mathrm{mg} / \mathrm{dL}$ yaitu 17 orang. Nilai tersebut menunjukkan bahwa banyak penderita SKA yang memiliki kadar kolesterol LDL tinggi dan berbahaya. Hasil rerata yang didapatkan pada kolesterol LDL, penderita yang memiliki kadar kolesterol LDL tertinggi yakni pada kelompok STEMI yaitu dengan rerata 146,5 $\pm 22,402 \mathrm{mg} / \mathrm{dL}$. Sedangkan pada penderita SKA dengan faktor risiko dislipidemia juga didapatkan rerata tertinggi pada kelompok STEMI yaitu $159 \pm 32,527 \mathrm{mg} / \mathrm{dL}$. Hal ini juga sesuai dengan penelitian yang dilakukan oleh Torry $^{12}$ dimana penderita dengan kolesterol LDL optimal berjumlah lebih sedikit dibandingkan penderita dengan kolesterol LDL diatas optimal yaitu hanya empat orang dan 14 penderita memiliki kadar kolesterol LDL diatas optimal. Kadar kolesterol LDL yang tinggi sangat berbahaya. Peningkatan kolesterol LDL merupakan predisposisi terjadinya aterosklerosis. $^{20}$ LDL berperan dalam proses penimbunan kolesterol dalam makrofag, sel otot polos serta matriks ekstra seluler dalam pembuluh darah sehingga bersifat aterogenik. ${ }^{21}$ LDL sangat erat hubungan dengan kejadian SKA dimana patofisiologinya adalah kerusakan pada lapisan endotel pembuluh darah koroner yang salah satu faktor risikonya disebabkan oleh oksidasi dari LDL-C. Kematian sel endotel akibat terjadinya oksidasi LDL ini menghasilkan respons inflamasi. Dimana respons dari angiotensin II, yang menyebabkan gangguan vasodilatasi, dan mencetuskan efek protrombik dengan melibatkan platelet dan faktor koagulasi. Hal ini menghasilkan respons protektif dimana akan terbentuk lesi fibrofatty dan fibrous, plak atherosklerotik, yang dipicu oleh inflamasi. Plak yang terjadi dapat menjadi tidak stabil (vulnerable) dan mengalami ruptur sehingga terjadi SKA. ${ }^{22}$

Pada penelitian trigliserida didapatkan jumlah terbanyak pada penderita dengan trigliserida $<150 \mathrm{mg} / \mathrm{dL}$ yaitu 48 orang. Pada penderita SKA dengan faktor risiko dislipidemia didapatkan lebih banyak penderita yang memiliki kadar trigliserida $\geq 150 \mathrm{mg} / \mathrm{dL}$ yaitu sebanyak 13 orang. Sedangkan pada penelitian nilai rerata kadar trigliserida didapatkan peningkatan paling tinggi pada kelompok UAP yakni sebesar $152,27 \pm 52,176 \mathrm{mg} / \mathrm{dL}$ dan pada penderita SKA dengan faktor risiko dislipidemia didapatkan rerata paling tinggi pada kelompok STEMI yaitu 196 $\pm 101,823$ $\mathrm{mg} / \mathrm{dL}$. Hal ini sesuai dengan penelitian yang dilakukan oleh Zahara $^{16}$ yang 
dilakukan di RS khusus jantung sumatera barat pada tahun 2013 dimana penderita dengan kadar trigliserida optimal didapatkan lebih banyak yaitu berjumlah 59 orang. Kadar trigliserida yang didapatkan pada penderita SKA pada penelitian ini kecuali pada penderita dengan faktor risiko dislipidemia tidak menunjukkan peningkatan yang bermakna dibandingkan peningkatan pada kadar kolesterol LDL dan penurunan kolesterol HDL. Hal ini mungkin disebabkan karena keterbatasan data pada penelitian ini, yaitu peneliti tidak menelusuri lebih lanjut penderita yang telah mendapatkan terapi sehingga berdampak pada penurunan kadar trigliserida pada responden. Peran peningkatan konsentrasi trigliserida sebagai prediktor terhadap penyakit kardiovaskular masih menjadi perdebatan. Hubungan antara trigliserida puasa dengan risiko kardiovaskular yang didapat berdasarkan analisis univariat melemah setelah dilakukan penyesuaian terhadap faktor lain terutama kolesterol HDL. Konsentrasi trigliserida yang tinggi sering disertai dengan konsentrasi kolesterol HDL yang rendah dan konsentrasi small, dense LDL tinggi sehingga diperkirakan pengaruh hipertrigliseridemia terhadap risiko kardiovaskular secara tidak langsung disebabkan oleh konsentrasi kolesterol HDL rendah dan konsentrasi small, dense LDL tinggi. ${ }^{9}$

\section{Simpulan dan Saran}

Dari penelitian ini dapat ditarik kesimpulan sebagai berikut :

1. Penderita SKA sebanyak 80 orang dengan jenis kelamin laki-laki 53 orang dan perempuan 27 orang, dimana 77 orang berusia 46 - > 65 tahun.

2. Kejadian SKA terbanyak didapatkan pada kelompok UAP yakni berjumlah 37 orang (46\%).

3. Dari 80 penderita sindrom koroner akut didapatkan 37 orang (46,25\%) adalah penderita yang memiliki kadar kolesterol total tinggi ( $\geq 200$ $\mathrm{mg} / \mathrm{dL}$ ), sebanyak 70 orang (87,5\%) memiliki kadar HDL rendah $(\leq 40-50 \mathrm{mg} / \mathrm{dL}), 58$ orang (72,5\%) memiliki kadar LDL tinggi (> $100 \mathrm{mg} / \mathrm{dL}$ ) dan 32 orang (40\%) adalah penderita yang memiliki kadar trigliserida tinggi $(\geq 150$ $\mathrm{mg} / \mathrm{dL}$ ).

\section{Saran}

1. Perlunya anamnesis lengkap dan edukasi pada pasien dan keluarga.

2. Pentingnya pemberian penyuluhan pada masyarakat mengenai faktor risiko sindrom koroner akut.

3. Dalam proses pengurusan surat penelitian diharapkan agar tidak memperlambat mahasiswa yang akan memulai penelitian.

4. Bagi penelitian selanjutnya agar lebih memperluas cakupan penelitianya khususnya dalam jumlah sampel dan lokasi penelitian, serta menggunakan metode analitik sehingga dapat lebih bermanfaat dalam perkembangan ilmu pengetahuan di bidang kedokteran.

\section{Daftar Pustaka}

1. Pambudi D. Gambaran profil lipid dan asam urat pada penderita jantung koroner di poliklinik RSUP Prof. dr. R. D. Kandou Manado tahun 2006-2010. Manado: Fakultas Kedokteran Universitas Sam Ratulangi;2011:1-10.

2. Setianto BY, Astuti I, Irawan B, Mubarika S. Corelation Between Matrix Metalloproteinase-9 (MMP9) And Troponin-I (cTn-I) in STElevation Myocardial Infarction (STEMI) and Non ST-Elevation Acute Coronary Syndrome (NSTEACS). Jurnal Kardiologi Indonesia; 2011;32:6.

3. The University of Kafkas. The Modification of Serum Lipids after 
Acute Coronary Syndrome and Importance in Clinical Practice. Turkey. 2011;7:273.

4. Dani, Gunawan J. Karakteristik

Penderita Infark Miokardium di Rumah Sakit Immanuel Bandung Periode 1 Januari 2012 - 31

Desember 2012. Fakultas

Kedokteran Universitas Kristen Maranatha. Bandung. 2015:2.

5. Adi PR. Pencegahan dan

Penatalaksanaan Aterosklerosis. Dalam : Setiati S, Alwi I, Sudoyo AW, Simadibrata KM, Setiyohadi B, Syam AF. Editor. Buku Ajar Ilmu Penyakit Dalam. Jilid II. Edisi keenam. Jakarta: Pusat Penerbitan Ilmu Penyakit Dalam; 2014. h:1427.

6. Irmalita, Juhar DA, Andrianto, Setianto BY, Tobing DP, Firman D, dkk. Pedoman Tatalaksana Sindrom Koroner Akut. Perhimpunan

Dokter Spesialis Kardiovaskular Indonesia. Edisi ke 3. Jakarta. 2015:2-3.

7. Josten S, Mutmainnah, Hardjoeno. Profil Lipid Penderita Diabetes Melitus Tipe 2 P. Bagian Patologi Klinik FK- UNHAS-BLU RS. Dr. Wahidin Sudirohusodo. Makassar. 2006:20.

8. Beny AS. Perbedaan Profil Lipid pada Pasien Infark Miokard Akut dan Penyakit Jantung Non Infark Miokard. Universitas Dipanegara. 2013:7.

9. Erwinanto, Santoso A, Putranto JNE, Tedjasukmana $\mathrm{P}$, Suryawan $\mathrm{R}$, Rifqi S, dkk. Pedoman Tatalaksana Dislipidemia. Perhimpunan Dokter Spesialis Kardiovaskular Indonesia. Edisi ke-I. 2013:2-14.

10. Siniawski D, Masson W, Estrada JLN, Giacomini M, Jaimovich G, Parcerisa F, dkk. Changes In The Lipid Profile of Patients With Acute Coronary Syndromes Within The First Days Of Hospitalization. 2010;73:239.
11. Arthania CDP. Perbedaan Profil Lipid Pada Pasien Diabetes Melitus Tipe 2 Dengan Komplikasi Nefropati Diabetik Stadium IV Dan Penyakit Jantung Koroner. Fakultas

Kedokteran Universitas Sebelas Maret. Surakarta. 2011:48.

12. Torry SRV. Gambaran Faktor Risiko Penderita Sindrom Koroner Akut. Manado: Fakultas Kedokteran Universitas Samratulangi; 2013:25.

13. Ramadhani BYS, Rotty LWA, Wantania F. Gambaran Hematologi pada pasien sindrom koroner akut yang dirawat di BLU RSUP Prof. Dr. R. D. Kandou Manado tahun 2010. Manado: Fakultas

Kedokteran Universitas Sam Ratulangi; 2010:13.

14. Jellinger PS, Smith DA, Mehta AE, Ganda O, Handelsman Y, Rodbard HW, dkk. American Association Of Clinical Endocrinologists'

Guidelines For Management of Dyslipidemia And Prevention of Atherosclerosis. 2012:10-11.

15. Rudyanto BS. Profil Lipid Darah pada

Pasien Penyakit Jantung

Koroner yang Dirawat Inap Di

Rumah Sakit Al Islam Bandung

Periode 1 Januari 2011 Sampai 31

Desember 2011. Fakultas

Kedokteran Universitas Islam Bandung. Bandung. 2012:53.

16. Zahara F, Syafri M, Yerizel E.

Gambaran Profil Lipid pada Pasien Sindrom Koroner Akut di Rumah Sakit Khusus Jantung Sumatera Barat Tahun 2011-2012. Fakultas Kedokteran Universitas Andalas. 2013:170.

17. Manurung D. Lipid Profiles of Acute Coronary Syndrome Patients Hospitalized in ICCU of Cipto Mangunkusumo Hospital. Jakarta: Fakultas Kedokteran Universitas Indonesia; 2006:196.

18. Anwar TB. Faktor Risiko Penyakit Jantung Koroner. Fakultas 
Kedokteran Universitas Sumatera Utara. 2004:6.

19. Pratiwi N. Hubungan High Density Lipoprotein Dengan Penurunan Fungsi Kognitif Pada Wanita Post Menopause. 2010:3.

20. Firdiansyah MH. Hubungan Antar Rasio Kadar Kolesterol Total Terhadap High-Density Lipoprotein (HDL) Dengan Kejadian Penyakit Jantung Koroner Di RSUD DR. Moewardi. Fakultas Kedokteran Universitas Muhammadiyah Surakarta. 2014:9.

21. Chandra T. Perbedaan Profil Lipid Remaja Dengan Orang Tua
Berpenyakit Jantung Koroner dan Bukan Jantung Koroner. Program Pascasarjana Magister Ilmu

Biomedik Program Pendidikan Dokter Spesialis Ilmu Kesehatan Anak Fakultas Kedokteran Universitas Diponegoro. Semarang. 2007:10.

22. Majid A. Penyakit Jantung Koroner: Patofisiologi, Pencegahan, Dan Pengobatan Terkini. Fakultas Kedokteran Universitas Sumatera Utara. Medan. 2007:3. 